\title{
Differential Handling of Toxic Chemicals by Stress Shock Algae
}

\author{
Hang-Yu Yu1, 2, Shujuan Wang1, 2 , Zongwei Cai ${ }^{2}$, Karen Poon ${ }^{1}$ (Corresponding Author) \\ ${ }^{1}$ Food Science and Technology Program, Division of Science and Technology, Beijing Normal University Hong Kong \\ Baptist University United International College, 29 Jinfeng Road, Tangjiawan, Zhuhai, Guangdong, P.R. China 519085 \\ 2Department of Chemistry, Faculty of Science, Hong Kong Baptist University, 224 Waterloo Road, Kowloon Tong, \\ Hong Kong SAR, China \\ karenpoon@uic.edu.hk
}

\begin{abstract}
Chlorella Pyrenoidosa was rich in various nutrients, so it has been marketed as health food for a period of time. Our result indicated that Chlorella Pyrenoidosa, isolated locally and morphologically identified by local authority, may manifest the toxicity of toxic contaminant by increasing its quantity, which may impose a potential food safety concern. In the 1-h incubation studies, Chlorella Pyrenoidosa was found to exhibit differential stress response to different environmental toxic contaminants. The dead algal cells were shown to bind organic toxic chemicals in the decreasing order of 2,4,6Trichlorophenol (TCP), $\rho$-Toluidine (TD), O-cresol (OC), 4Bromoaniline (4BA), 4-Nitrophenol (4NP) and 4-Nitroaniline (4NA). The live algal cells exhibited additional handling of organic compounds in the form of internalization, desorption and secretion. Based on the HPLC analysis, algae was found to secrete the toxic organic chemical 4NA that originally exposed to $i t$, to the medium with the amount exceeded the original added quantity. The manner of net secretion was concentration dependent. Higher the exposure concentration induced more chemical to be secreted. Spectrum analysis using multiple wavelengths did not reveal significant change in the spectrum absorption of test chemicals. The observed phenomena might indicate that the local algae were triggered by the exposure of $4 N A$ to re/produce the same compound and net secrete out from the cell, and potentially manifested the toxicity of 4NA. The net secretion process was found not to be oxygen dependent. It was hypothesized the secretion may be a stress shock event leading to a condition of cell leakage. Further studies were required to elucidate the mechanism. The internalization of TCP, TD and $4 B A$ by live algal cell were observed and the process was inhibited in the absence of oxygen. For 4NP, desorption was observed in live algal cells .
\end{abstract}

Keywords: Algae, Chlorella Pyrenoidosa, Stress Shock, Environmental Toxic chemicals
(C) Copyright 2012 Authors - This is an Open Access article published under the Creative Commons Attribution License terms (http://creativecommons.org/licenses/by/2.0). Unrestricted use, distribution, and reproduction in any medium are permitted, provided the original work is properly cited.

\section{Introduction}

Algae were known to be inducible by environmental stress to produce secondary metabolites (Chen et al 2009, Peckol et al 1996, Sotka et al 2002). Similar induction phenomena have been observed in various studies (Graneli et al 2008, Pansch et al 2008, Teplitski et al 2004, Van der Step et al 2009). Producing secondary metabolite by algae was a kind of defense mechanism to increase their chances of survival or decrease pathogenic attack. For example, some algal species might produce secondary metabolites under nutrient limitation or altered nutrient $(\mathrm{N}, \mathrm{P})$ ratios, which would inhibit potential competitors and so increased their competitiveness in grasping resources (Graneli et al 2008). Accumulation of unpalatable secondary metabolites (Amsler \& Fairhead 2006) was one of the strategies to increase their survival by reducing the chance of being grazed upon (Pansch et al 2008, Sotka et al 2002). The secondary metabolite might have harmful effect to aquatic lives and human, and so they were named as allelochemicals. Allelochemicals included flavonoids, terpenoids, glucosinolates, alkaloids and etc.

Although some of the secondary metabolites were toxic to aquatic lives and birds leading to the great disasters to the environment, many other secondary metabolites were found to be useful for human beings. Many of them were biologically active and medicinally useful. For example, sulfated polysaccharides and terpenoids that isolated from algae were found to have anti-cancer (Ganesan et al 2011, Kim et al 2010, Khanavi et al 2010, Pereira et al 2011) and anti-microbial (Das et al 2007) functions. Other functions 
included antihypertension (Inoue et al 1995), immunemodulation (Itoh et al 1993).

Algae were known to have high nutrient content. Many of their phytochemicals and secondary metabolites were found to be biologically active and with potential clinical uses. Therefore, Chlorella has been used and sold in the market as health food for a period of time. Intake of the algal supplement was reported to reduce dioxin absorption from foods and also promote the secretion from body (Morita et al 2001). In addition, the rapid and ease of growth of algae made them be one of the best vehicle to produce useful materials for industries, for example, pigments, vitamins, fatty acids, polysaccharide, steroids, carotenoids, lectins (Wikfor \& Ohno 2001), oil for the production of biodiesel and etc.

Algal cell wall has a complex architecture with polymeric fiber-constructed framework that was interspersed with various low molecular weight colloidal polymers and inorganic ions (Seigel and Seigel 1973). These materials have high metal uptake and selectivity, and so made algae be useful in environmental remediation to remove contaminations (Davis et al 2003).

As the algae were potentially useful in various applications, understanding on how the algae respond to the environmental changes are very important. Environmental contaminants not only affect the growth of algae, but also trigger various responses from algae, e.g. bio-absorption, degradation, or secretion of secondary metabolites. These responses would either be useful to human or harmful to the environment. Therefore, we would investigate the behaviour of algae in response to various environmental stimulations.

In the present studies, we would investigate how the algae Chlorella Pyrenoidosa handle and respond to the environmental stress. Environmental contaminants used in the studies included 2,4,6-trichlorophenol (TCP), $\rho$-Toluidine (TD), O-Cresol (OC), 4-bromoaniline (4BA), 4-Nitroaniline (4NA) and 4-Nitrophenol (4NP). All these environmental contaminants were known to be toxic (web-1). TCP and TD were found to be carcinogenic, while TCP, TD, 4BA and 4NA were harmful to aquatic lives (web-1).

\section{Materials and Methods}

TCP of purity $>97 \%$ (GC) were purchased from SigmaAldrich; TD from Shanghai JinShanTing new chemical factory; OC, 4BA, 4NA and 4NP from Sinopharm Chemical Reagent Co. Ltd. Stock solutions of the standards were prepared with ethanol to the concentration of $5 \mathrm{mg} / \mathrm{ml}$ and stored at $4^{\circ} \mathrm{C}$ prior to use.

\subsection{Cultivation condition and algal growth}

Chlorella Pyrenoidosa was isolated locally and was morphologically identified by accredited authority in Freshwater Algae Culture Collection of the institute of Hydrobiology China. The algal cell was cultured in Trisacetate-phosphate (TAP) medium (Gorman \& Levine 1965) and maintained by periodically transfer to new medium. The liquid algal culture in flask was covered with filter of pore size of $0.22 \mu \mathrm{m}$, continuously shaken with shaker at $120 \mathrm{rpm}$, and incubated in an environmental chamber at $25^{\circ} \mathrm{C}$ with light (4800 lux)/dark cycle of 16/8-h.

\subsection{Experimental protocol}

\subsubsection{Dead algal cells preparation}

Dead algal cells were prepared by autoclaving the algal cell culture at late exponential growth phase (3 days) at $120^{\circ} \mathrm{C}$ for $15 \mathrm{~min}$ and the autoclaved cells were then spraydried. The dried cells were kept at $-18^{\circ} \mathrm{C}$ prior to use. The cells would be washed three times with deionized water before being used for experiment. The cell concentration was estimated by spectrophotometric measurement at A680 nm and the use of hemocytometer (Guillard \& Sieracki 2005).

\subsubsection{Live algal cells preparation}

Algal cell culture at late exponential growth phase (3 days) were harvested by centrifugation at $5000 \mathrm{~g}$ for $5 \mathrm{~min}$. The collected cells were washed with deioned water for three times before being suspended in deioned water.

\subsubsection{Concentration studies procedure}

Dilution of the $5 \mathrm{mg} / \mathrm{mL}$ stock solution using deionised water was performed to make test solution with concentration of $1000 \mathrm{ppm}, 750 \mathrm{ppm}, 500 \mathrm{ppm}$ and $250 \mathrm{ppm}$. For the concentration studies, $20 \mu \mathrm{L}$ of $1000 \mathrm{ppm}$ was added to $0.98 \mathrm{ml}$ algal cell in $2-\mathrm{ml}$ vial to yield the final chemical concentration of $20 \mathrm{ppm} ; 20 \mu \mathrm{L}$ of $750 \mathrm{ppm}$ to $0.98 \mathrm{ml}$ algal cell to final concentration of $15 \mathrm{ppm} ; 20 \mu \mathrm{L}$ of $500 \mathrm{ppm}$ to $0.98 \mathrm{ml}$ algal cell to final concentration of $10 \mathrm{ppm} ; 20 \mu \mathrm{L}$ of $250 \mathrm{ppm}$ to $0.98 \mathrm{ml}$ algal cell to final concentration of $5 \mathrm{ppm}$.

The vials were capped and mixed, before the samples were incubated in environmental chamber with light intensity of 4800 lux at room temperature at $25^{\circ} \mathrm{C}$ for 1 hour. For the other group of experiment, samples would be incubated at $4{ }^{\circ} \mathrm{C}$ in dark for 1 hour. For nitrogen-bubbled samples, the algal cells were prepared by bubbling with nitrogen gas for 15 min before being added with the tested chemical, and incubated in environmental chamber with light intensity of 4800 lux at room temperature at $25^{\circ} \mathrm{C}$ for 1 hour. After the incubation, the supernatant was then collected by centrifugation at $9000 \mathrm{~g}$ for $5 \mathrm{~min}$, and used directly for HPLC analysis.

HPLC system used for the chemical analysis was Agilent Series 1200 liquid chromatography (Palo Alto, CA USA) coupled with a binary pump, an in-line degasser, a Symmetry Shield ${ }^{\mathrm{TM}}$ RP8 $(3.0 \mathrm{~mm} \times 150 \mathrm{~mm})$ column and a diode array detector. A gradient elution program with water and methanol as the mobile phases was used. The gradient program started with $45 \%$ methanol changed to $95 \%$ in 10 min and held for $8 \mathrm{~min}$. The flow rate was $0.55 \mathrm{~mL}$ and injection volume was $10 \mu \mathrm{L}$. The UV detection was set at 
multiple wavelengths at $210 \mathrm{~nm}, 240 \mathrm{~nm}, 250 \mathrm{~nm}, 254 \mathrm{~nm}$, $280 \mathrm{~nm}, 310 \mathrm{~nm}$ and $350 \mathrm{~nm}$. Only one chemical would be used in each experiment.

\section{Results}

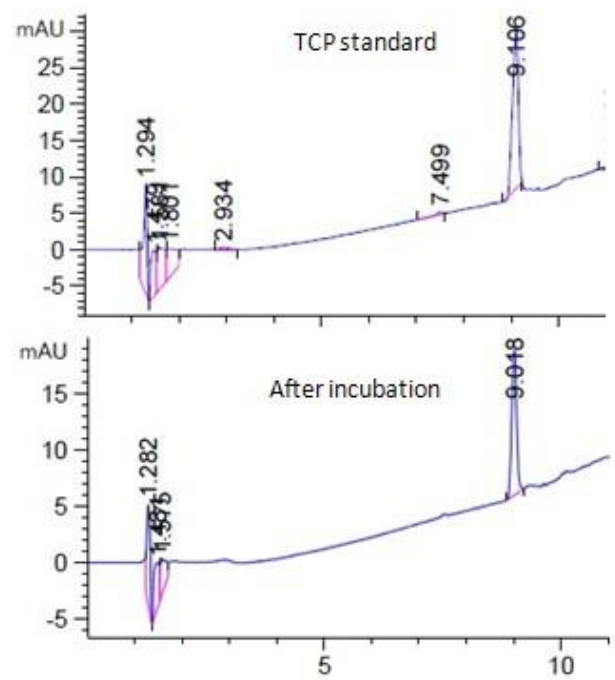

Fig.1a HPLC spectrum of 15ppm TCP standard and sample.

Fig. 1a showed the HPLC analysis of 15ppm TCP standard and the corresponding live algal cell sample at room temperature under light. The peak of TCP was found at $9 \mathrm{~min}$. (Fig. 1a) When compared the live algal sample with the standard, no significant amount of degradation product of TCP was observed during the experimental period (Fig. 1a). Similar negative observation was found for other samples at different incubation conditions (Fig. 1a, unpublished data).

When TCP was incubated with dead algal cells, it would bind onto the cells, (Fig. 1b) and decrease the TCP concentration in the supernatant. Higher the given concentration, more would be adhered to cells (Fig. 1b). The maximum concentration of being bound to algal cells was about $0.5 \mathrm{ppm} / 1 \mathrm{E}+07 \mathrm{cells}$ with the binding kinetics saturated at concentration above 15 ppm (Fig. 1b).

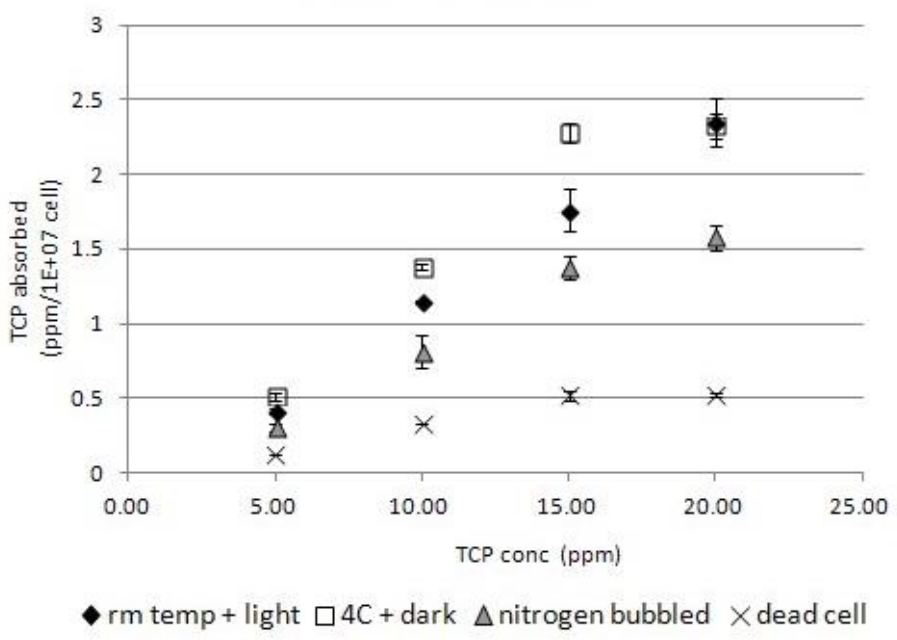

Fig. 1b Absorption of TCP.

When TCP was applied to live algal cells, it was found to be further absorbed by cells, and so decrease the TCP concentration of TCP more than that in dead cells (Fig.1b). Higher the TCP concentration given, more would be absorbed by live algae. The absorption was found to saturate at concentration greater than 15 ppm (Fig. 1b). Incubation condition at $4{ }^{\circ} \mathrm{C}$ in dark slightly increased the TCP absorption by the live algal cells (Fig. 1b), while the nitrogen-bubbling effect may reduce the absorption (Fig. 1b).

Fig. 2a showed the HPLC spectrum of $15 \mathrm{ppm}$ TD standard and the corresponding supernatant sample of live algal cell at room temperature under light. TD was peaked at 3.8 min (Fig. 2a). When comparing the spectrum of the sample with the standard, no significant amount of degradation product was observed (Fig. 2a). Similar negative observation was found in other TD samples in different incubation conditions (Fig. 2a, unpublished data).

Similar to TCP, TD would bind onto dead algal cells with the highest concentration at $0.38 \mathrm{ppm} / 1 \mathrm{E}+07 \mathrm{cells}$ that was lower than that of TCP (Fig. 1b). Live algal cells seemed to absorb TD into the cell, and so the chemical disappeared more than that observed in dead algal cell samples. The absorption of TD by live algal cells was concentration dependent. Higher the TD concentration was, higher was the amount of chemical being absorbed by cells (Fig. 2b). Incubation of samples at $4^{\circ} \mathrm{C}$ in dark increased the absorption of TD by algal cells (Fig. 2b). Nitrogen bubbled algal cells was not significantly different from regular algal cells in TD absorption (Fig. 2b). 

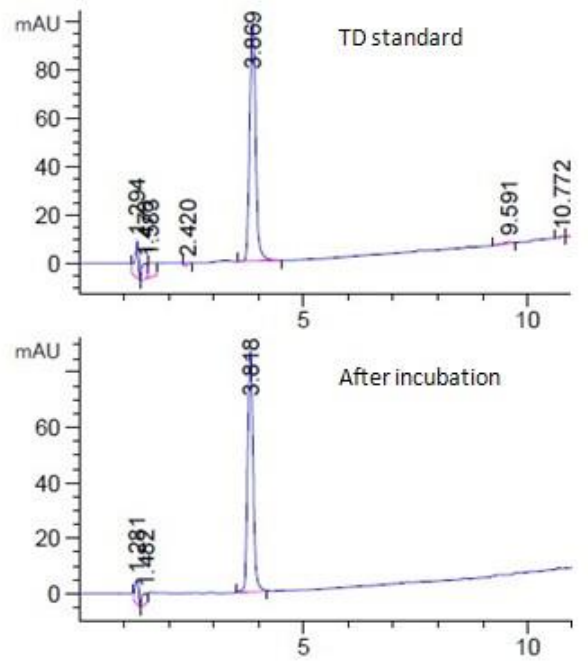

Fig.2a HPLC spectrum of 15ppm TD standard and sample.

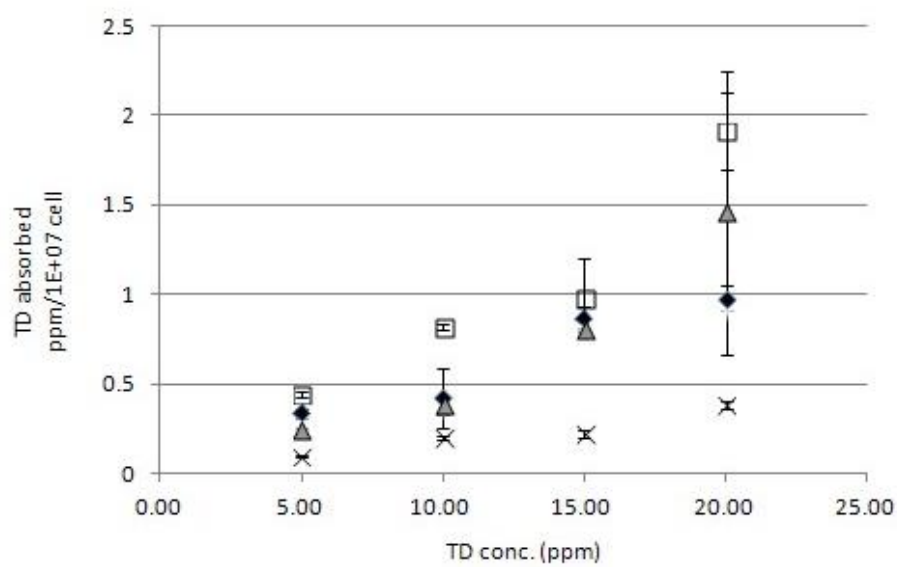

- rm temp + light $\square 4 \mathrm{C}+$ dark $\Delta$ nitrogen bubbled $\times$ dead cell

Fig. 2b Absorption of TD.

Fig. 3a showed the HPLC spectrum of $15 \mathrm{ppm}$ OC standard and the corresponding supernatant sample of live algal cell at room temperature under light. OC was peaked at $5.6 \mathrm{~min}$ (Fig. 3a). Similar to the above two test chemicals, no significant amount of degradation product was observed in the analysis. Similar negative observation was found in other OC tested samples in various incubation conditions (Fig. 3a, unpublished data).

Fig. $3 \mathrm{~b}$ showed the biosorption of OC by algal cells. Similar to TCP and TD, OC would adhere onto the dead algal cell in a concentration dependent manner. The highest concentration bound by dead cells was estimated at $0.22 \mathrm{ppm} / 1 \mathrm{E}+07$ cells. Compared with TCP and TD, relatively less amount of OC would bind onto the dead algal cell (Fig. 1$3 b)$.
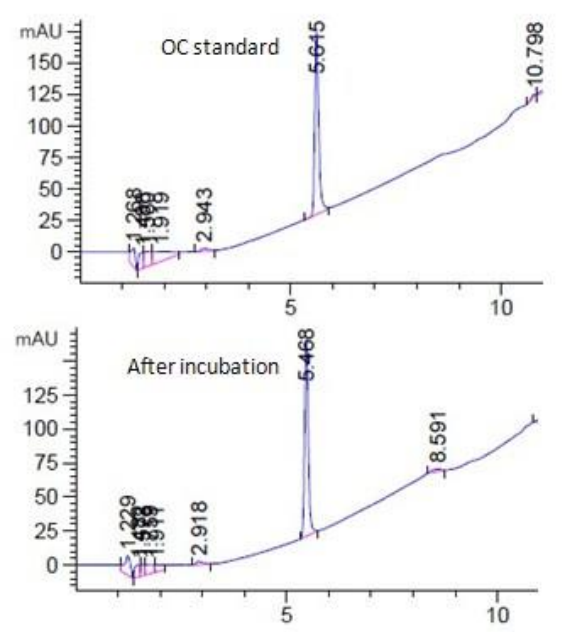

Fig.3a HPLC spectrum of 15ppm OC standard and sample.

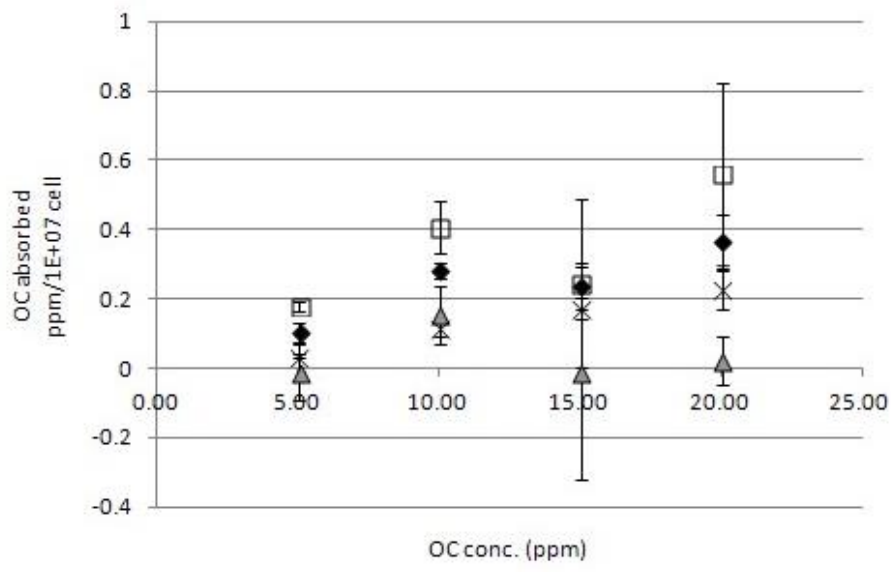

- rm temp + light $\square 4 \mathrm{C}+$ dark $\Delta$ nitrogen bubbled $\times$ dead cell

Fig. 3b Absorption of OC.

When the live algal cells exposed to OC, more chemical was found to be uptake by the cells (Fig. 3b). Similarly, incubation at $4^{\circ} \mathrm{C}$ in dark increased the chemical uptake by live algal cells (Fig. 3b). When nitrogen-bubbled algal cell samples were used in the incubation experiment, the amount of OC being uptake by cells significantly decreased (Fig. 3b). For the samples incubated at concentration higher than $15 \mathrm{ppm}$ further decreased the uptake ability (Fig. 3b). Some of the individual nitrogen bubbled algal samples were found to have negative values of absorption indicating a status of net secretion.

Fig. 4a showed the HPLC spectrum of $15 \mathrm{ppm} 4 \mathrm{BA}$ standard and the corresponding live algal cell sample incubated with $15 \mathrm{ppm}$ 4BA for 1 hour at room temperature under light. 4BA was found to peak at 5.9 min (Fig. 4a). Similar to the above three chemicals, no significant amount of degradation product was found in the sample during the experimental period (Fig. 4a). Similar negative observation 
was found in other 4BA samples under different test conditions (Fig. 4a, unpublished data).
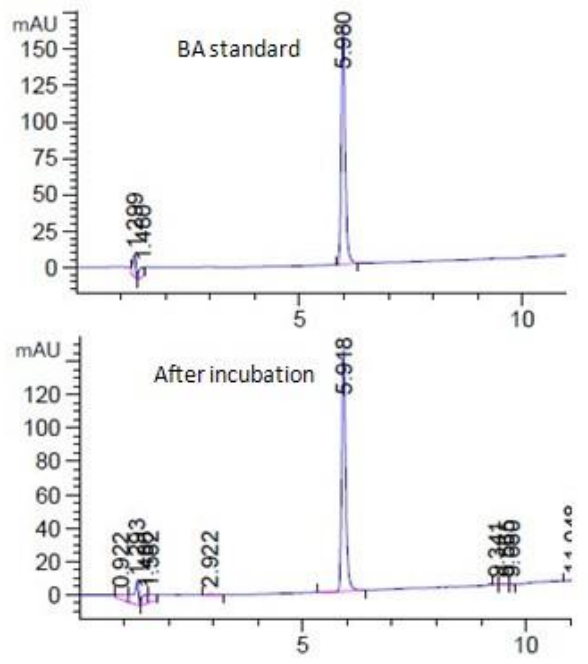

Fig.4a HPLC spectrum of 15ppm 4BA standard and sample.

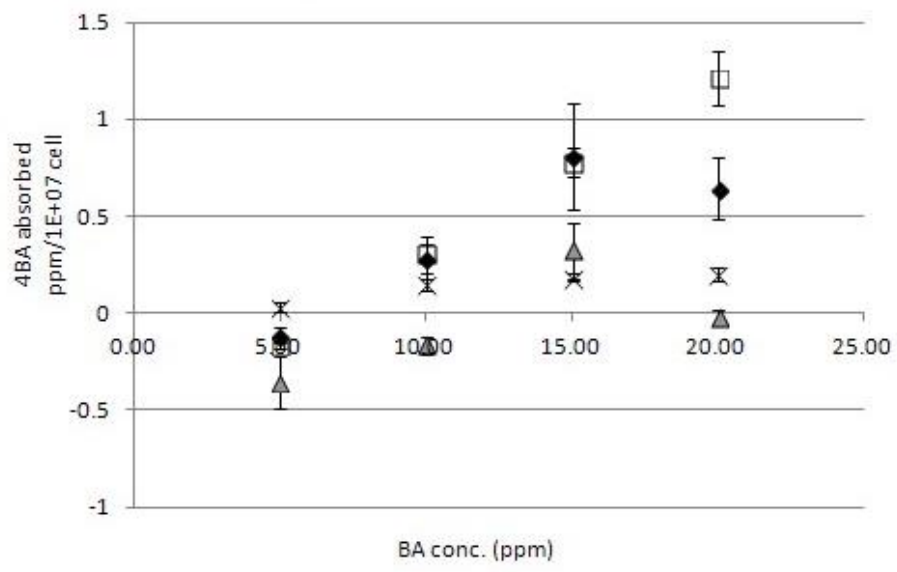

- rm temp + light $\square 4 \mathrm{C}+$ dark $\Delta$ nitrogen bubbled $\times$ dead cell

Fig. 4b Absorption of 4BA.

Similar to the above three chemicals, 4BA was found to bind onto the dead algal cell in a concentration dependent manner (Fig. 4b). The maximum amount of 4BA bound to the dead algal cells was $0.22 \mathrm{ppm} / 1 \mathrm{E}+07$ cells that was less than that of TCP and TD (Fig. 1b,2b,4b).

More 4BA was found to be uptake by live algal cells than dead cells, which indicated the chemical was absorbed into the live algal cells. Similar to the above three chemical experiments, incubation of live algal cell samples at $4{ }^{\circ} \mathrm{C}$ in dark increased the chemical uptake by the algal cells (Fig. 4b). Nitrogen-bubbled algal cell samples were found to have less chemical uptake than the other test groups (Fig. 4b). Some of the samples were even shown to have negative chemical uptake, i.e. net chemical secretion to the medium and so some of the absorption values were negative (Fig. 4b).

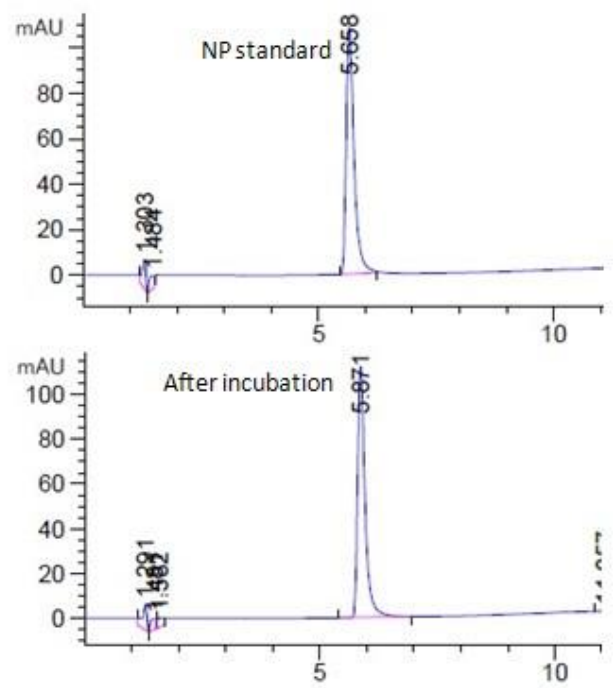

Fig.5a HPLC spectrum of 15ppm 4NP standard and sample.

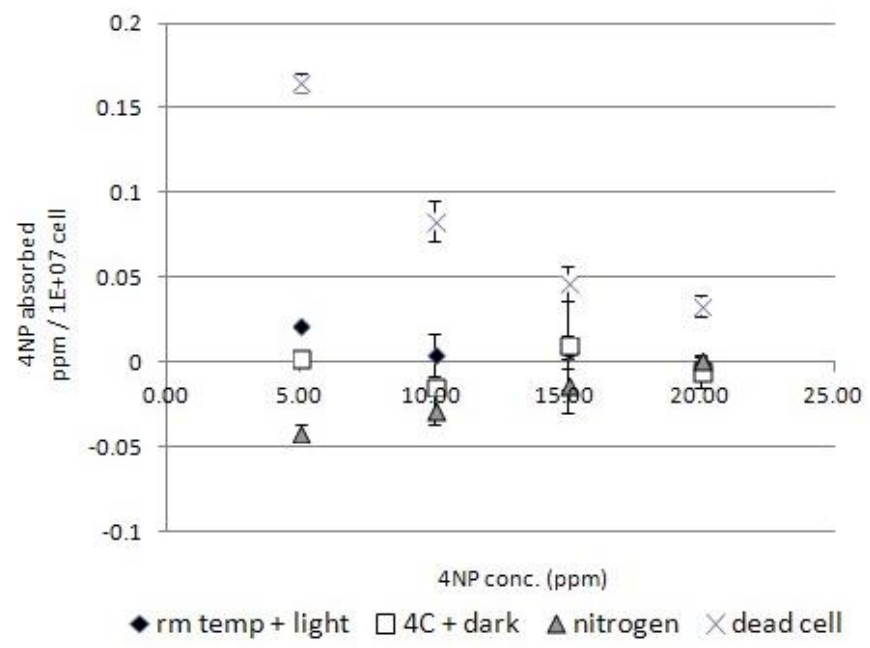

Fig. 5b Absorption of 4NP.

Fig. 5a showed the HPLC spectrum of $15 \mathrm{ppm} 4 \mathrm{NP}$ standard and the corresponding live algal cell samples at room temperature under light. $4 \mathrm{NP}$ was peaked at $5.8 \mathrm{~min}$. (Fig. 5a). The 4NP peak shown for the live algal cell sample was found to increase (Fig. 5a), which indicated a net chemical secretion by algae occurred. Similar to the above four chemicals, no significant amount of degradation product was observed in other samples under various incubation conditions (Fig. 5a, unpublished data).

The interaction of $4 \mathrm{NP}$ and algal cells were found to be quite different from that for the above four chemical groups. Although 4NP would adhere onto the dead algae in a concentration dependent manner, the relationship between 
binding and concentration was inversely correlated. (Fig. 5b) It was different from that of the above captioned chemicals with direct correlation (Fig. 1-4b). For 4NP binding to dead cells, higher the concentration of $4 \mathrm{NP}$ was used in the experiment, lower amount of chemical was bound by the dead cells (Fig. 5b). Using live algal cells in the incubation experiment did not increase the chemical uptake. Instead, less chemical was uptake by live cell than that by dead cells (Fig. 5b). Incubation of live algal cell sample at $4{ }^{\circ} \mathrm{C}$ in dark further decreased the chemical uptake by live cells (Fig. 5b). Nitrogen-bubbled algal cell samples were found to have even less ability for chemical uptake. On the contrary, chemical was found to be net secreted by nitrogen-bubbled algal cells to the medium (Fig. 5b) with the highest secretion occurred at the lowest concentration of 5ppm (Fig. 5b).

Fig. 6a showed the HPLC spectrum of $15 \mathrm{ppm} 4 \mathrm{NA}$ standard and the corresponding live algal cell samples at room temperature under light. $4 \mathrm{NA}$ was peaked at $4.7 \mathrm{~min}$ (Fig. 6a). The 4NA peak shown for the live algal cell sample was found to increase, which indicated the condition of net secretion of 4NA by the algal cells (Fig. 6a). Similar to the above five chemicals, no significant amount of degradation product was observed for samples under various incubation conditions (Fig. 6a, unpublished data).

Fig. $6 \mathrm{~b}$ showed the biosorption of 4NA by algal cells. 4NA was relatively less bound to the dead algal cells (Fig. 6b) than to other test chemicals (Fig. 1-5b). Incubation of 4NA with live algal cells, no chemical was found to bind on the algal cells. Instead, net secretion of $4 \mathrm{NA}$ by live algal cells was observed (Fig. 6b), the chemical secretion was found to be concentration-dependent (Fig. 6b). Higher the concentration of 4NA used for the experiment, higher amount of 4NA secretion was observed (Fig. 6b). Incubation of live algal cell samples at $4^{\circ} \mathrm{C}$ in dark decreased the net secretion (Fig. 6b). Nitrogen-bubbled algal cells were found to have a higher ability of net secretion than the regular cells (Fig. 6b).

\section{Discussion}

Our HPLC spectrums of various tested chemicals have shown that analysis of individual compounds could be nicely conducted (Fig. 1-6a). For all the test samples, we did not observe significant amount of degradation products for the corresponding tested compounds during the one-hour incubation period (Fig. 1-6a, unpublished data). The decrease in chemical concentration after the one hour incubation should be mainly due to the biosorption, including the process of adsorption and absorption, of the chemical by the cells.

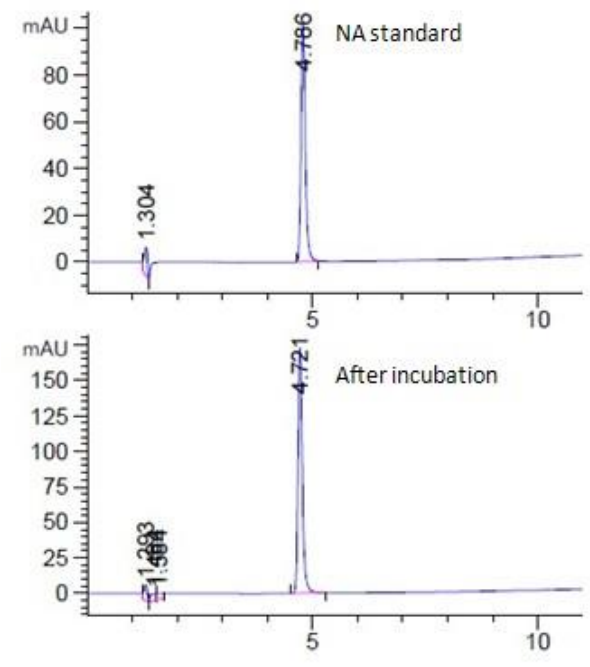

Fig.6a HPLC spectrum of 15ppm 4NA standard and sample.

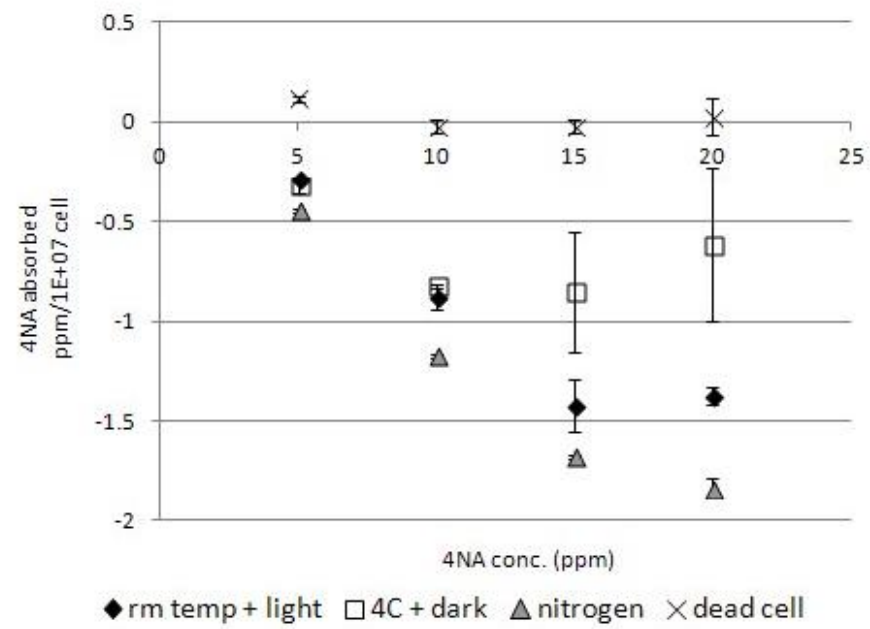

Fig. 6b Absorption of 4NA.

Our data indicated that when the dead algal cell was incubated with various chemicals, biosorption of organic chemicals were observed (Fig. 1-5b). The degree of biosorption decreased in the order of TCP, TD, OC, 4BA, 4NP and 4NA (Fig. 1-6b). The selectivity of biosorption probably reflected to the unique cell wall properties of Chlorella Pyrenoidosa in forming electrostatic interaction and complexation (Davis et al 2003). For TCP, TD, OC and 4BA, the biosorption by dead algal cell was concentrationdependent. Higher the added amount of chemical, higher was the degree of biosorption (Fig. 1-4b). In contrast, the biosorption of 4NP (Fig. 5b) was negatively correlated with the exposed concentration. Higher the added amount of chemical, lower was the degree of biosorption. The negative correlation of 4NP concentration with the degree of biosorption could be explained by two hypotheses, 1) the 
increase in exposed 4NP concentration increased the chance of 4NP being shed off from the cell wall, and so reduced the amount of 4NP being attached; 2) the increase in exposed $4 \mathrm{NP}$ concentration increased the chance of self-interaction, which may interfere its binding to the cell wall. However, further studies were required for the understanding of the mechanism.

However, the live algae exhibited differential handling to various compounds. The uptake of TCP (Fig. 1b), TD (Fig. 2b), OC (Fig. 3b), 4BA (Fig. 4b) were much higher in live cell than the dead, while the uptake of 4NP (Fig. 5b) and 4NA (Fig. 6b) were lower in live cell than the dead. The higher chemical uptakes (Fig.1-4b) indicated that the internalization of chemicals occurred in the live algae. Similar to the effect of blue-light in enhancing the uptake of organic compound (Kamiya \& Saitoh 2002), incubation of the cell in the absence of light also promoted the uptake of organic compound (Fig. 1-4b). The chlororespiration was considerably enhanced in Chlorella incubated with glucose in the dark (Chemeris et al 2004), and accompanied with heterotrophic mode of metabolism took place in algae. As algae were both photoautotrophic and heterotrophic (Qiao et al 2009), absence of light may enhance the algae to switch from photoautotrophic to heterotrophic mode of metabolism. Utilisation of organic compound as carbon or nitrogen sources (Laliberte \& Hellebust 1990) might be the possible reason to explain the decreased amount of chemicals in the medium (Fig. 1-4b). The absorption of compound was decreased in nitrogen-bubbled algal cells. As anaerobic condition created in nitrogen-bubbled medium decreased the oxygen level and also decreased the chemical internalization, it might imply the internalization process was oxygen dependent.

The handling of 4NP and 4NA by Chlorella Pyrenoidosa (Fig. 5-6b) were quite different from that of other test compounds. The uptake of 4NP (Fig. 5b) was lower in live cell than in dead cell, but the value was not negative. It indicated that the live cell had an ability to desorb the attached 4NP back to the medium. Desorption process observed for 4NP was not affected by the absence of light. Utilization of $4 \mathrm{NP}$ by algae as carbon source might not be a significant process. In the test condition using low concentration of $4 \mathrm{NP}$ at $5 \mathrm{ppm}$, net secretion of small amount of $4 \mathrm{NP}$ by nitrogen-bubbled algal cell upon the exposure of the tested chemical was observed (Fig. 5b).

The amount of 4NA bound to dead algae was found to be minimal (Fig. 6b). In live cell, no biosorption of 4NA was observed. In the contrary, the amount of 4NA found in sample became higher after incubation. Spectrum analysis with multiple wavelengths did not reveal significant changes in spectrum absorption of tested compound (unpublished data). The result indicated that there was net secretion of 4NA by algal cells to the medium. The secretion process was concentration dependent. Higher the exposed 4NA concentration was, higher was the net $4 \mathrm{NA}$ secretion. In the absence of light, amount of 4NA secretion decreased (Fig.6b). The decrease of $4 \mathrm{NA}$ in medium might be due to the hetertrophic mode of algal metabolism in utilizing organic compound as carbon source, and so decreased the amount of 4NA. Furthermore, the net secretion process was promoted in nitrogen bubble algal cells (Fig. 6b). It may imply that the net secretion may not be highly oxygen dependent. The bubbling effect of nitrogen may also induce stress to algae triggering the net secretion.

Secretion of organic compounds by stress shock algae Chlorella was reported in other studies (Laliberte \& Hellebust 1990), although the mechanism may not be the same. I hypothesized that the secretion observed in the present study was the result of a stress shock event leading to the condition of cell leakage. Further studies were required in order to understand the mechanism. As the toxins secreted by algae was usually in small amount, it was seldom considered to be a threat to environment. However, the concentrated algae used as a dried product may increase the concentration of toxic chemical and so increased the risk significantly. As 4NA was toxic and harmful to both aquatic lives and human (web-1), the induction of 4NA net secretion by Chlorella Pyrenoidosa may impose a potential food safety concern.

\section{Conclusion}

There were at least four handling processes observed in local Chlorella Pyrenoidosa to environmental contaminants. They included 1) adsorption to the cell wall; 2) internalization; 3) desorption; 4) secretion. Similar to metal ions (Davis et al 2003), algae also displayed high selectivity to organic compound in biosorption. The internalization of TCP, TD OC and 4BA by algae were observed. The decrease of chemical concentration induced by the absence of light implied the heterotrophic mode of algal metabolism took place to utilize the organic compound as carbon source. The internalization process was oxygen dependent, and so it was decreased in anaerobic condition observed in nitrogenbubbled algal cells. The net secretion process observed in 4NA was concentration-dependent. The process may not be highly oxygen dependent, or be induced by the bubbling effect.

The secretion of 4NA was hypothesized to be a stress shock event leading to the condition of cell leakage. Further studies were required in order to elucidate the mechanism and establish possible control measure. Nevertheless, the increase in the quantity of toxic 4NA by Chlorella Pyrenoidosa potentially imposed a food safety concern.

\section{Acknowledgements}

This research work was financially supported by UIC Research Grant R201207. 


\section{References}

Amsler, C. D., Fairhead, V. A. (2006) Defensive and sensory chemical ecology of brown algae. Adv Bot Res 43:1-91.

Chen T., Wei D., Chen G., Wang Y., Chen F., (2009) Employment of organic acids to enhance astaxanthin formation in heterotrophic Chlorella Zofingiensis. Journal of Food Processing and Preservation 33: 271-284

Chemeris, Y. K., Shenderova, L. V., Venediktov, Rubin, A. B. (2004) Activation of Chlororespiration increases Chlorophyll fluorescence yield in Chlorella adapted to darkness at high temperature. Biology Bulletin. Vol 31, no.2, pp. 143-150.

Das, A., Yoon, S-H., Lee, S-H., Kim, J-Y., Oh, D-K., Kim, S-W (2007) An update on microbial carotenoid production: application of recent metabolic engineering tools. Applied Microbiology and Biotechnology, 77:505-512

Davis, T. A., Voleskya, B., Mucci, A. (2003) A review of the biochemistry of heavy metal biosorption by brown algae. Water Research 37:4311-4330

Ganesan, P., Noda, K., Manabe, Y., Ohkubo, T., Tanaka, Y., Maoka, T., Suqawara, T. (2011) Siphonaxanthin, a marine carotenoid from green algae, effectively induces apoptosis in human leukemia (HL-60) cells. Biochima et Biophysica Acta (BBA) - General Subjects, Vol. 1810 (5), pp. 497-503.

Gorman, D. S., Levine, R. (1965) Cytochrome f and plastocyanin: their sequence in the photosynthetic electron transport chain of Chlamydomonas reinhardi. Proceedings of The National Academy of Sciences PNAS, USA 54:1665-1669.

Graneli, E., Weberg, M., Salomon, P. S. (2008) Harmful algal blooms of allelopathic microalgal species: The role of eutrophication. Harmful Algae 8:94-102

Guillard, R. R., Sieacki, M. S. (2005) Counting cells in cultures with light microscope. "Algal Culturing Techniques" 239252, Academic Press.

Laliberte, G., Hellebust, J.,A. (1990) Arginine utilization by Chlorella autotrophica and Chlorella saccharophua. Physiol. Plant. 79:57-64.

Inoue K, Mukaiyama Y, Oka H, Misawa H. (1995) Clinical effects of Chlorella in hypertensive men. J Jpn Soc Nutr Food Sci 48:485-489.

Itoh, H., Noda, H., Amano, H., Zhuaug, C., Mizuno, T., Ito, H. (1993) Antitumor activity and immunological properties of marine algal polysaccharides, especially fucoidan, prepared from Sargassum thunbergii of Phaeophyceae. Anticancer Res., 13, 2045-2052.

Kamiya, A., Saitoh, T. (2002) Blue-light -control of the uptake of amino acids and of ammonia in Chlorella mutants. Physiologia Plantarum 116: 248-254.

Khanavi, M., Nabavi, M., Sadati, N., Shams Ardekani, M., Sohrabipour, J., Nabavi, S. M., Ghaeli, P., Ostad, S. N. (2010) Cytotoxic activity of some marine brown algae against cancer cell lines. Biological Research Vol. 43 (1), pp. 31-7.
Kim, E. J., Park, S. Y., Lee, J-Y., Park, J. H. Y. (2010) Fucoidan present in brown algae inducesapoptosis of human colon cancer cells. Gastroenterology 10:96

Morita, K., Ogata, M. Hasegawa, T. (2001) Chlorophyll Derived from Chlorella Inhibits Dioxin Absorption from the Gastrointestinal Tract and Accelerates Dioxin Excretion in Rats. Environmental Health Perspectives 1091 number 3

Pansch, C., Gomez, I., Rothanusler, E. (2008) Species-speciWc defense strategies of vegetative versus reproductive blades of the PaciWc kelps Lessonia nigrescens and Macrocystis integrifolia Marine Biology, 155:51-62

Peckol, P., Krane, J. M., Yates, J. L. (1996) Interactive effects of inducible defense and resource availability on phlorotannins in the North Atlantic alga Fucus vesiculosus. Marine Ecology Progress Series, 138:209217.

Pereira, D. M., Cheel, J., Areche, C., San-Martin, A., Rovirosa, J., Silva, L. R., Valentao, P., Andrade P. B. (2011) AntiProliferative Activity of Meroditerpenoids Isolated from the Brown Alga Stypopodium flabelliforme against Several Cancer Cell Lines. Marine Drugs 9: 852-862

Qiao, H., Wang, G., Zhang, X. (2009) Isolation and characterization of Chlorella sorokiniana GXNN01 (Chlorophyta) with the properties of heterotrophic and microaerobic growth. Journal of Phycology 45: 11531162

Seigel, B. Z., Seigel, S. M. (1973) The chemical composition of algal cell walls. CRC Critial Reviews in Microbiology, 1:126.

Sotka E, Taylor RB, Hay ME (2002) Tissue-specific induction of resistance to herbivores in a brown seaweed: the importance of direct grazing versus waterborne signals from grazed neighbours. J Exp Mar Biol Ecol 277:1-12

Teplitski, M., Chen, H., Rajamani, S., Mengsheng, G., Merighi, M., Sayre, R. R., Robinson, J. B., Rolfe, B. G., Bauer, W. D. (2004) Chlamydomonas reinhardtii Secretes Compounds That Mimic Bacterial Signals and Interfere with Quorum Sensing Regulation in Bacteria. Plant Physiology 134: 137-146

Van der Stap, I., Vos, M., Kooi, B. W., Mulling, B. T. M., van Donk, E., Mooij, W. M. (2009) Algal defenses, population stability, and the risk of herbivore extinctions: a chemostat model and experiment. Ecological Research 24: 1145-1153

Wikfors G.H., Ohno M.(2001) Impact of algal research in aquaculture. Journal of Phycology, 37, 968-974

Web Sites:

Web 1:

http://www.fisher.co.uk consulted on March 12, 2012 